\title{
EDUKASI WARGA SEKOLAH DALAM RANGKA PERWUJUDAN KANTIN SEHAT DI SEKOLAH
}

\author{
Sri Kadaryati ${ }^{1 *}$, Yunita Indah Prasetyaningrum ${ }^{1}$, Satria Nugraha ${ }^{2}$ \\ ${ }^{1}$ Universitas Respati Yogyakarta, Yogyakarta, Indonesia \\ ${ }^{2}$ RSUD Dr. (HC) Ir. Soekarno Bangka Belitung, Kepulauan Bangka Belitung, Indonesia \\ *srikadaryati3@gmail.com
}

\begin{abstract}
Abstrak: Sekolah Menengah Pertama (SMP) Negeri 1 Depok memiliki fasilitas bangunan kantin yang permanen beserta pengelolanya sebagai unsur penunjang utama penyelenggaraan kantin sehat di sekolah. Namun, hal ini belum didukung dengan penyelenggaraan jajanan sehat dan aman di sekolah. Penjual kantin sekaligus sebagai penjamah makanan perlu ditingkatkan pengetahuannya terkait penyelenggaraan makanan sesuai dengan syarat kebersihan (higiene) sanitasi makanan untuk menjamin pangan yang aman dan sehat. Siswa sebagai konsumen kantin juga perlu mendapatkan pengetahuan yang baik sebagai acuan dalam pemilihan pangan jajanan. Kegiatan pengabdian kepada masyarakat ini berupa edukasi dalam bentuk penyuluhan sebagai rangkaian kegiatan pendampingan penyelenggaraan kantin sehat di sekolah di SMP Negeri 1 Depok, Sleman, Yogyakarta. Sasaran edukasi yaitu siswa kelas VII dan VIII serta penjamah makanan di kantin sekolah. Tujuan program ini untuk meningkatkan pengetahuan siswa terkait dengan pemilihan makanan jajanan sehat, serta memberikan pengetahuan kepada petugas kantin dalam menyediakan pilihan pangan jajanan yang lebih sehat dan aman. Evaluasi kegiatan edukasi terhadap pengetahuan siswa, dilihat berdasarkan hasil pre-test dan post-test. Pemberian edukasi dapat meningkatkan tingkat pengetahuan siswa secara statistik. Kegiatan edukasi kepada petugas kantin dilakukan dengan media Whatsapp Group. Hasil kegiatan ini menunjukkan adanya sikap yang positif pada penjamah mengenai penyelenggaraan kantin sehat dengan penerapan higiene sanitasi makanan dan pemilihan pangan sehat. Di samping itu, pengetahuan petugas kantin meningkat meskipun tidak signifikan secara statistik. Pengamatan kondisi kantin sekolah setelah dua bulan pelaksanaan edukasi menunjukkan belum adanya perubahan pada jenis makanan yang dijual di kantin, perilaku penjamah makanan, maupun pada fasilitas kantin. Program edukasi gizi mampu meningkatkan pengetahuan siswa dan penjamah makanan tentang pemilihan makanan jajanan aman dan sehat. Namun, peningkatan pengetahuan ini belum cukup untuk mewujudkan penyelenggaraan kantin sehat di sekolah.
\end{abstract}

Kata Kunci: kantin sehat, sekolah, edukasi, gizi, pemilihan makanan

\begin{abstract}
SMP Negeri 1 Depok has a permanent canteen building facility as well as a canteen manager, which are the main supports in the implementation of a healthy canteen at school. However, it has not been supported by implementation of healthy and safe snacks in schools. Food handlers in canteen need to increase their knowledge about food service in accordance with food hygiene and sanitation, to ensure safe and healthy food. Students as canteen consumers also need to get the good knowledge as reference in choosing snack food in the canteen. This community service program consists of education as a series implementation of healthy school canteen at SMP Negeri 1 Depok, Sleman, Yogyakarta. The participants were $t^{\text {th }}$ and $8^{\text {th }}$ students and food handlers in the canteen. This program aims to increase students'knowledge concerning the selection of healthy foods, and to give knowledge to the food handlers in providing healthier and safer food choices. The evaluation of students' knowledge was based on pre-test and posttest. The delivery of education can increase knowledge level statistically. The education activities for the food handler was done using Whatsapp group. The results of this program reveal that there was positive attitude of food handler about providing healthy school canteen arrangement with application of higiene and sanitation, and healthy food choices. Food handler knowledge was increased, but not statistically significant. Observing school canteen after two months of education showed no change in the type of food choice in the school canteen, food handlers behavior, and cafeteria facility. Nutrition education programs were able to improve students' knowledge of healthy food and good food choices. However, the better knowledge was not enough to actualize a healthy canteen in the school.
\end{abstract}

Keywords: healthy canteen, school, education, nutrition, food choice 


\section{Pendahuluan}

Prevalensi overweight dan obesitas di Indonesia meningkat dalam dua dekade terakhir, tidak hanya pada orang dewasa, tetapi juga pada anak-anak dan remaja. Berdasarkan wilayah demografi, overweight dan obesitas lebih banyak terjadi di daerah perkotaan dengan pendidikan dan pendapatan yang tinggi (Rachmi, Li, Alison, 2017). Proporsi overweight dan obesitas pada remaja mengalami peningkatan secara berturut-turut berdasarkan Riset Kesehatan Dasar tahun 2007, 2013, dan 2018. Prevalensi overweight dan obesitas sebesar $16 \%$ pada remaja berusia 13-15 tahun dan $13,5 \%$ pada remaja berusia $16-18$ tahun. Selain itu, sebanyak $8,7 \%$ remaja berusia 13-15 tahun dan 8,1\% remaja berusia 16-18 tahun mengalami status gizi kurus dan sangat kurus. Data Riskesdas 2018 juga menunjukkan bahwa 25,7\% remaja berusia $13-15$ tahun dan 26,9\% remaja berusia 16-18 tahun berstatus gizi pendek dan sangat pendek. Pemerintah Indonesia telah mempromosikan Gerakan Masyarakat Sehat (GERMAS) sejak tahun 2010. Namun, konsumsi buah dan sayur yang menjadi Indikator GERMAS belum menunjukkan perbaikan dibandingkan dengan hasil Riskesdas tahun sebelumnya (Badan Penelitian dan Pengembangan Kesehatan Kementerian Kesehatan RI, 2010).

Kebiasaan dan asupan makan sangat menentukan status gizi anak usia sekolah (Badan Penelitian dan Pengembangan Kesehatan Kementerian Kesehatan RI, 2010). Remaja usia sekolah (12-16 tahun) membutuhkan konsumsi pangan yang cukup dan bergizi seimbang, untuk mendukung proses pertumbuhan dan perkembangan (BPOM, 2013). Data menyebutkan bahwa konsumsi energi dan protein pada anak sekolah berada di bawah angka kecukupan minimal (Badan Penelitian dan Pengembangan Kesehatan Kementerian Kesehatan RI, 2010). Konsumsi pangan jajanan pada anak sekolah atau remaja diharapkan memberikan kontribusi terhadap asupan energi dan zat gizi lain yang berguna bagi proses pertumbuhan dan perkembangan anak (Hamida et al., 2012). Di samping itu, kebiasaan mengonsumsi makanan jajanan menjadi salah satu penunjang dalam pemenuhan asupan makan pada anak usia sekolah (Mâsse \& de Niet, 2013); Templeton et al., 2005). Konsumsi makanan jajanan pada anak sekolah atau remaja diharapkan mampu memberikan kontribusi sebanyak 15-20\% pemenuhan kecukupan gizi (Hamida, Khairuna, \& Zulaekah, 2012). Konsumsi makanan selingan di sekolah sangat penting untuk mengontrol gula darah sehingga anak tetap berkonsentrasi pada pelajaran dan aktivitas lain di sekolah (BPOM, 2013). Penelitian pada anak SMP menunjukkan adanya hubungan antara kebiasaan jajan dengan status gizi (Rohmah Rohmawati, \& Sulistiyani, 2020).

Lingkungan sekolah menjadi faktor kuat yang membentuk kebiasaan makan siswa (Mensink, Schwinghammer, \& Smeets, 2012). Konsumsi makanan dipengaruhi oleh aspek penyediaan makanan. Terbatasnya ketersediaan pangan jajanan di lingkungan sekolah menyebabkan praktik pemilihan pangan jajanan yang tidak sesuai. Hasil penelitian di USA menyatakan bahwa anak-anak lebih banyak terpapar makanan dan minuman yang tidak sehat, seperti snack dan soft drink dari kantin sekolah (Anderson, Butcher, \& Levine, 2003). Hasil studi di Filipina menyatakan bahwa sebagian besar makanan dan minuman yang dijual di kantin sekolah termasuk jajanan yang tidak sehat (Cartagena, 2014). Hasil penelitian pada sekolah di wilayah perkotaan Belanda juga menunujukkan pilihan makanan yang tidak sehat lebih sering 
disajikan daripada pilihan sehat (Timmermans et al., 2018). Mudahnya akses untuk memperoleh makanan dan minuman yang tinggi gula-garam-lemak serta rendah gizi merupakan salah satu food environment yang yang berkontribusi terhadap munculnya obesitas (obesogenic environment) (Lake, 2018; Powell \& Educator, 2016). Konsumsi pangan cepat saji dan makanan ringan yang berlebihan merupakan salah pencetus terjadinya obesitas. Jenis pangan cepat saji biasanya mengandung tinggi natrium dan lemak serta rendah serat. Makanan ringan umumnya juga rendah serat dan mengandung natrium tinggi namun memiliki nilai gizi yang rendah (BPOM, 2013).

Siswa menghabiskan banyak waktu sehari-hari di sekolah. Oleh karena itu, penyediaan makanan di sekolah penting untuk diperhatikan (Syafirah \& Andrias, 2012). Kantin sekolah menjadi salah satu wadah penyediaan makanan untuk anak di sekolah. Mengingat pentingnya pangan jajanan yang sehat dan aman bagi anak maka perlu digalakkan program kantin sehat sekolah. Mitra kegiatan ini yaitu SMP Negeri 1 Depok, Sleman, Yogyakarta. Penanggung jawab kantin telah mengikuti kegiatan yang diselenggarakan sebelumnya, yaitu edukasi penyelenggaraan kantin sehat di sekolah kepada para kepala sekolah dan pengelola kantin sekolah menengah pertama di wilayah Kecamatan Depok, Sleman, Yogyakarta (Prasetyaningrum \& Kadaryati, 2021). SMP Negeri 1 Depok memiliki fasilitas bangunan kantin yang permanen, yang merupakan salah satu penunjang utama dalam penyelenggaraan kantin sehat di sekolah. Manajemen sekolah telah menunjuk beberapa guru untuk menjadi pengelola kantin sekolah. Pihak sekolah juga terbuka atas masukan yang membangun terkait dengan kesehatan sekolah.

Fasilitas fisik pada kantin sekolah belum didukung dengan penyelenggaraan jajanan sehat dan aman di sekolah. Berdasarkan hasil pengamatan di lapangan, diketahui bahwa makanan jajanan yang tersedia di kantin sekolah SMP Negeri 1 Depok belum memenuhi syarat makanan sehat untuk sekolah. Beberapa penjual masih menyediakan makanan tinggi natrium, minuman instan, snack tinggi lemak. Menu sayuran dan buah belum tersedia pada menu makanan di kantin. Di samping itu, penyajian makanan masih menggunakan wadah terbuka dan petugas penjamah makanan juga belum memaksimalkan penggunaan alat pelindung diri (APD).

Penyelenggaraan kantin sehat di sekolah membutuhkan empat pilar dasar yang saling berhubungan, yaitu komitmen dan manajemen sekolah, sumber daya manusia, sarana dan prasarana, dan mutu pangan (Februhartanty et al., 2018). Lebih lanjut dijelaskan bahwa selain warga sekolah, penyelenggaraan kantin sehat di sekolah juga membutuhkan dukungan dari orang tua/wali siswa (Rahayu et al., 2015). Penyelenggaraan kantin sehat di sekolah juga harus memperhatikan adanya sisi ekonomi dalam penyelenggaraan kantin. Kantin merupakan tempat bertemunya penjual yang memiliki kepentingan ekonomi dari hasil penjualan makanan, dan siswa sebagai konsumen yang memanfaatkan jasa penjual di kantin. Oleh karena itu, diperlukan suatu program penyelenggaraan kantin sehat yang dapat mengakomodasi kepentingan ekonomi dari penjual di kantin, tetapi tetap memperhatikan aspek kesehatan makanan untuk siswa.

Petugas kantin sekaligus sebagai penjamah makanan perlu ditingkatkan pengetahuannya mengenai penyelenggaraan makanan sesuai dengan syarat higiene sanitasi makanan untuk 
menjamin pangan yang aman dan sehat. Siswa sebagai konsumen kantin juga perlu mendapatkan pengetahuan yang baik sebagai acuan dalam pemilihan pangan jajanan. Meningkatnya pengetahuan siswa dan petugas kantin diharapkan menjadi langkah awal perubahan sikap terhadap pemilihan dan penyediaan pangan aman dan sehat.

\section{Metode}

Kerangka pemecahan masalah terdapat pada Bagan 1. Kegiatan pengabdian kepada masyarakat dilakukan melalui program edukasi yang menyasar pada siswa dan penjamah makanan di kantin sekolah. Mitra dalam kegiatan ini yaitu SMP Negeri 1 Depok, Sleman, Yogyakarta. Pemberian edukasi dilaksanakan pada bulan Mei-Juni 2019.

Kegiatan edukasi siswa dilakukan dalam bentuk penyuluhan. Beberapa penelitian menunjukkan bahwa pemberian edukasi melalui penyuluhan tentang keamanan makanan dan jajanan sehat mampu meningkatkan pengetahuan siswa (Hamida et al., 2012; Sumarni Rosidin, \& Sumarna, 2020). Sasaran edukasi siswa yaitu 321 siswa dari kelas VII dan VIII (Tabel 1). Tujuan program ini adalah untuk meningkatkan pengetahuan siswa mengenai pemilihan makanan jajanan sehat. Evaluasi kegiatan edukasi dilihat berdasarkan sampling data pengetahuan dari hasil pengisian lembar pre-test dan post-test. Pemberian materi dan diskusi dilaksanakan di aula sekolah, sedangkan pre-test dan post-test dilaksanakan di kelas masingmasing. Materi penyuluhan mengenai makanan jajanan sehat bagi siswa, ditinjau dari aspek keamanan pangan dan pemilihan makanan berdasarkan konsep traffic light label. Konsep Traffic Light (TL) Label dikembangkan oleh Food Standards Agency (FSA) dengan menitikberatkan informasi nilai gizi pada zat gizi tertentu, yaitu lemak total, lemak jenuh, gula, dan natrium. Zat gizi dikategorikan menjadi tiga indikator warna yaitu tinggi (merah), medium (kuning), dan rendah (hijau) berdasarkan angka yang ditetapkan oleh The European Regulation for Nutrition and Health Claims. Studi di Inggris dan Australia menunjukkan bahwa TL lebih berhasil membantu konsumen memilih produk yang sehat. Penerapan pedoman berbasis TL di kafetaria menunjukkan bahwa uji coba TL dapat membantu konsumen dalam memilih makanan sehat secara cepat (Sari, Palupi, \& Jamil, 2016).

Tabel 1. Peserta Kegiatan Edukasi kepada Siswa

\begin{tabular}{ccc}
\hline No. & Kelas & Jumlah Siswa \\
\hline 1 & VII A & 30 \\
\hline 2 & VII B & 26 \\
\hline 3 & VII C & 27 \\
\hline 4 & VII D & 28 \\
\hline 5 & VII E & 23 \\
\hline 6 & VII F & 30 \\
\hline 7 & VIII A & 23 \\
\hline 8 & VIII B & 31 \\
\hline 9 & VIII C & 22 \\
\hline 10 & VIII D & 26 \\
\hline 11 & VIII E & 26 \\
\hline 12 & VIII F & 29 \\
\hline
\end{tabular}


Kegiatan edukasi kepada enam petugas kantin yang tercantum pada Tabel 2. Edukasi dilakukan dengan media Whatsapp Group. Pemilihan metode edukasi ini didasarkan pada pertimbangan kesediaan waktu kelompok sasaran yang terbatas. Penelitian sebelumnya yang menyebutkan adanya efek kognitif yang baik dengan pemanfaatan Whatsapp sebagai media edukasi (Suryani, 2017). Penggunaan Whatsapp group menunjang aktivitas pembelajaran di luar jam sekolah (Anggraini \& Djatmiko, 2019). Tujuan edukasi kepada petugas kantin yaitu memberikan pengetahuan mengenai penyediaan pilihan pangan jajanan yang lebih sehat dan aman. Materi yang disampaikan mengenai konsep higiene sanitasi makanan dan traffic light label pada makanan jajanan. Materi dibagi menjadi 12 chat yang dikirim dengan frekuensi pengiriman materi sebanyak tiga kali dalam satu minggu. Evaluasi kegiatan dilihat berdasarkan pengetahuan dan sikap menggunakan alat bantu kuesioner.

Tabel 2. Peserta Edukasi kepada Petugas Kantin

\begin{tabular}{cccc}
\hline No. & Karakteristik & $n=6$ & $\%$ \\
\hline 1 & Jenis Kelamin & & \\
& Perempuan & 6 & 100 \\
& Laki-laki & - & - \\
\hline 2 & Usia & & - \\
& $<25$ & - & 16,7 \\
& $25-35$ & 1 & 83,3 \\
& $>35$ & 5 & - \\
& Pendidikan & & - \\
& SD & - & 66,7 \\
& SMP & 4 & 33,3 \\
& SMA & 2 & \\
& Sarjana & &
\end{tabular}

Penentuan lokasi kegiatan Observasi penyelenggaraan kantin sekolah

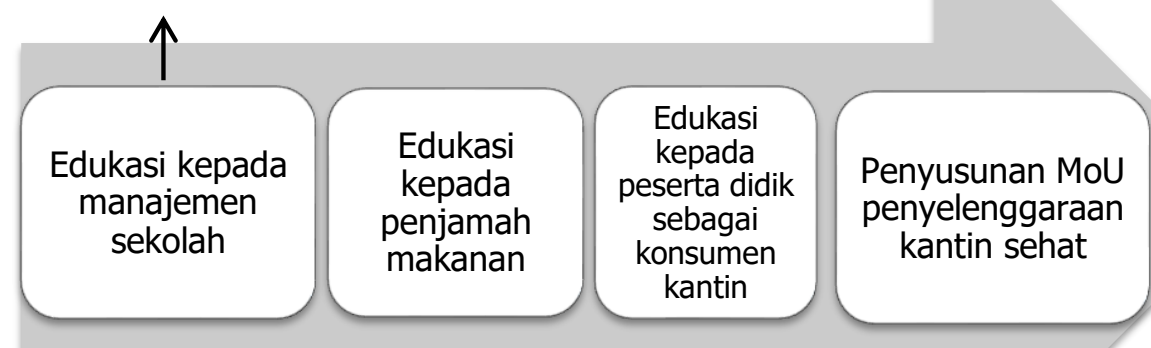

Bagan 1. Kerangka Pemecahan Masalah

\section{Hasil dan Pembahasan}

\section{Evaluasi Kegiatan Edukasi kepada Siswa}

Evaluasi kegiatan edukasi terhadap pengetahuan siswa, dilihat berdasarkan hasil pre-test dan post-test. Sampling data diambil sebanyak 10 siswa untuk setiap kelas. Terdapat tiga 
subjek dengan nilai pengetahuan setelah penyuluhan lebih rendah daripada sebelum penyuluhan, sebanyak 99 orang dengan nilai tetap, dan 18 orang mempunyai pengetahuan yang lebih baik dari sebelum penyuluhan (Gambar 1). Analisis statistik dilakukan dengan uji Wilcoxon, menggunakan program komputer. Tabel $\mathbf{3}$ menunjukkan pengaruh pemberian edukasi terhadap pengetahuan siswa. Pemberian edukasi dapat meningkatkan tingkat pengetahuan siswa secara statistik. Terdapat perbedaan pengetahuan yang bermakna antara sebelum dan setelah diberikan edukasi $(p=0,000)$.

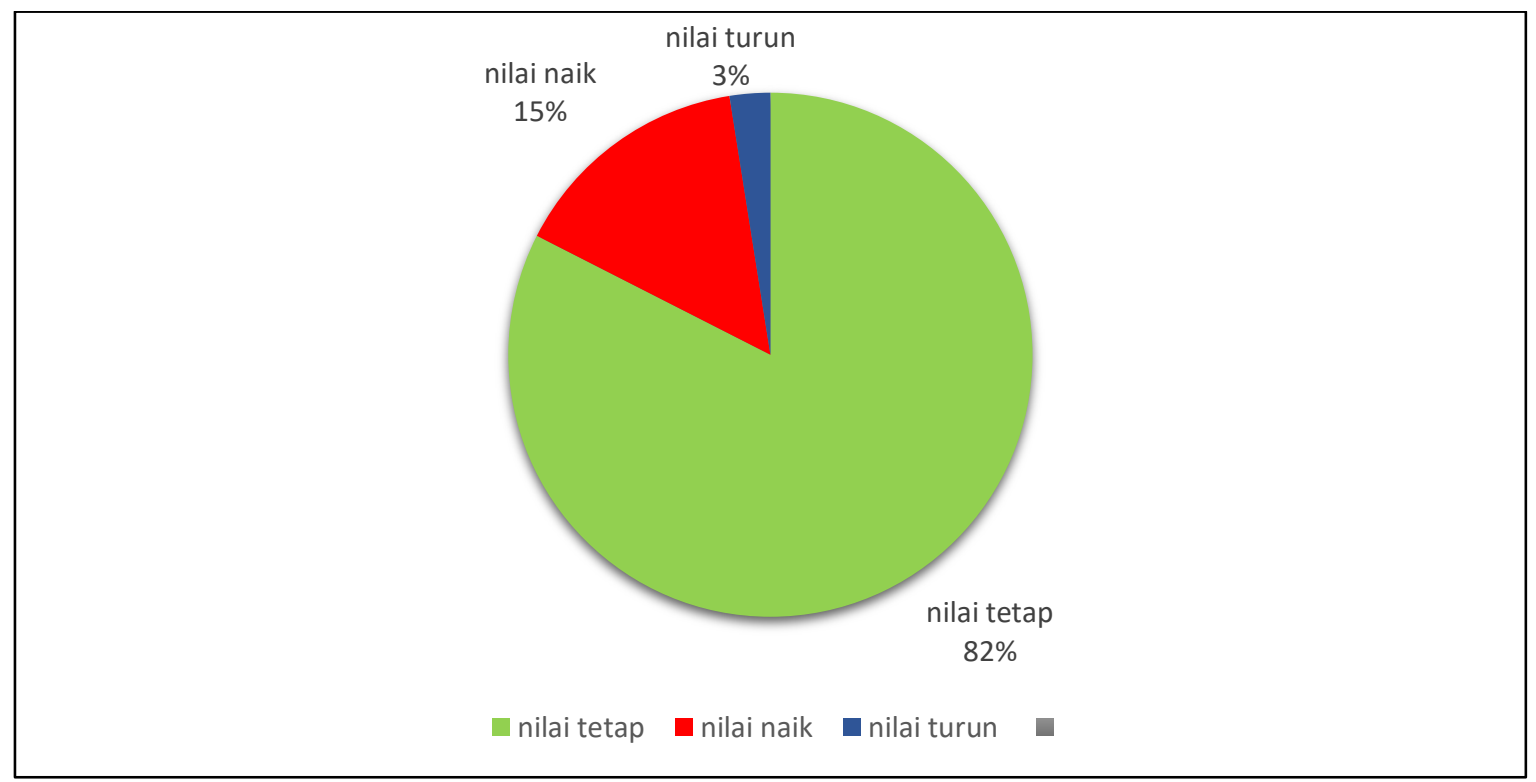

Gambar 1. Persentase Perubahan Nilai Pengetahuan Peserta Edukasi Siswa

Siswa merupakan salah satu konsumen kantin sekolah. Pola makan dan daya beli siswa perlu diperhatikan dalam manajemen penyelenggaran kantin sehat di sekolah. Perubahan pola perilaku jalan pada siswa diharapkan dapat mempengaruhi penyediaan makanan di kantin sekolah. Di sisi lain, petugas penjamah makanan turut berperan dalam pemilihan jenis jajanan yang disediakan oleh kantin. Pengetahuan penjamah yang baik diharapkan mendukung penyediaan jajanan sehat di kantin sekolah.

Tabel 3. Pengetahuan Siswa

\begin{tabular}{lccc}
\hline \multicolumn{1}{c}{ Pengetahuan } & $\mathrm{n}$ & Median (min-max) & $p$ \\
\cline { 1 - 3 } Pre-test & 120 & $5(1-7)$ & $\left.0,000^{*}\right)$ \\
\cline { 1 - 2 } Post-test & 120 & $7(4-8)$ & \\
${ }^{*}$ signifikan $\mathrm{p}<0,05 ;$ uji Wilcoxon & &
\end{tabular}

\section{Evaluasi Kegiatan Edukasi kepada Penjamah Makanan}

Kegiatan edukasi oleh tim pengabdi ini dilaksanakan dengan sasaran pada petugas kantin sebagai penyedia makanan di kantin. Hasil kegiatan ini menunjukkan adanya sikap yang positif pada penjamah mengenai penyelenggaraan kantin sehat dengan penerapan dasar higiene sanitasi makanan dan penerapan traffic light label. Penerapan higiene sanitasi makanan oleh petugas kantin merupakan salah satu dasar dari sistem keamanan makanan di kantin sekolah, sedangkan traffic light labe/ menjadi salah satu dasar pemilihan pangan jajanan sehat yang 
disediakan di kantin sekolah. Evaluasi pada petugas kantin dilihat melalui perbedaan pengetahuan dan sikap petugas antara sebelum dan sesudah pemberian edukasi mengenai penyelenggaraan kantin sehat. Evaluasi ini dilakukan pada enam petugas kantin yang diberikan edukasi. Tabel 4 menunjukkan perbedaan skor pengetahuan dan sikap petugas kantin, yang dianalisis statistik menggunakan Paired T-test.

Tabel 4. Pengetahuan dan Sikap Petugas Kantin

\begin{tabular}{lccc}
\hline & $\begin{array}{c}\text { Pre-test } \\
(\text { Mean } \pm \text { SD })\end{array}$ & $\begin{array}{c}\text { Post-test } \\
(\text { Mean } \pm \text { SD })\end{array}$ & $p$ \\
\hline Pengetahuan & $90,67 \pm 5,715$ & $94,17 \pm 5,269$ & 0,076 \\
\hline Sikap & $77,00 \pm 2,449$ & $93,67 \pm 2,338$ & $0,000^{*}$
\end{tabular}

${ }^{*}$ signifikan, $p<0,05$; uji Paired $T$

Tabel 4 menunjukkan adanya peningkatan pengetahuan petugas kantin, tetapi tidak signifikan secara statistik. Adanya peningkatan secara spesifik terlihat pada perubahan sikap petugas kantin. Usia responden turut mempengaruhi pengetahuan para penjamah makanan. Semakin tinggi usia maka pengetahuan dan pengalaman yang dimiliki semakin banyak. Semakin cukup umur seseorang maka tingkat pengetahuan seseorang akan menyebabkan seseorang lebih matang dalam berfikir dan bekerja. Hasil penelitian pada kader posyandu menunjukkan adanya hubungan antara tingkat pengetahuan, pendidikan, dan usia dengan kualitas laporan kegiatan posyandu (Nurayu, 2013). Sikap merupakan kecenderungan untuk bertindak, tetapi sikap belum tentu diwujudkan dalam tindakan. Hal ini disebabkan perwujudan tindakan memerlukan stimulus tertentu untuk mewujudkan perilaku yang diinginkan (Azwar, 2016).

\section{Evaluasi Penyelenggaraan Kantin Sehat}

Kegiatan edukasi merupakan suatu upaya agar masyarakat berperilaku kesehatan dengan salah satu cara berupa pemberian informasi. Kegiatan ini membutuhkan waktu lama untuk mengubah perilaku masyarakat, namun akan bertahan lama apabila perilakunya diadopsi oleh masyarakat. Peningkatan pengetahuan sebagai hasil dari kegiatan edukasi, menjadi faktor predisposisi dari perubahan perilaku (Notoatmodjo, 2014). Pengamatan kondisi kantin sekolah dilakukan dalam kurun waktu dua bulan setelah pelaksanaan edukasi kepada siswa maupun petugas kantin. Kegiatan ini dilakukan dengan tujuan untuk melihat pengaruh peningkatan pengetahuan siswa maupun pengetahuan dan sikap penjamah makanan terhadap penyelenggaraan kantin sekolah. Hasil pengamatan di kantin sekolah menunjukkan belum adanya perubahan pada jenis makanan yang dijual di kantin, perilaku penjamah makanan, maupun pada fasilitas kantin. Terlihat ketidaksesuaian antara konsep traffic light labe/maupun higiene sanitasi makanan dari segi petugas maupun makanan yang dijual, antara lain: beraneka ragam makanan jajanan yang tinggi kandungan lemak dan gula (aneka minuman olahan dan penggunaan gula pasir yang berlebihan pada minuman segar) serta jajanan dengan bahan tambahan pangan tinggi natrium (saus, mie instan, bumbu tabur); belum tersedianya pilihan menu sayuran dan buah pada menu makanan di kantin. Berdasarkan higiene sanitasi makanan, beberapa makanan siap konsumsi belum dikemas dalam kondisi tertutup. Perilaku petugas 
kantin secara umum baik, tetapi masih ditemukan beberapa pengelola kantin yang belum menggunakan alat pelindung diri (APD) saat melayani konsumen, seperti penutup kepala terstandar dan masker, serta tidak menggunakan penjepit makanan saat menyentuh makanan.
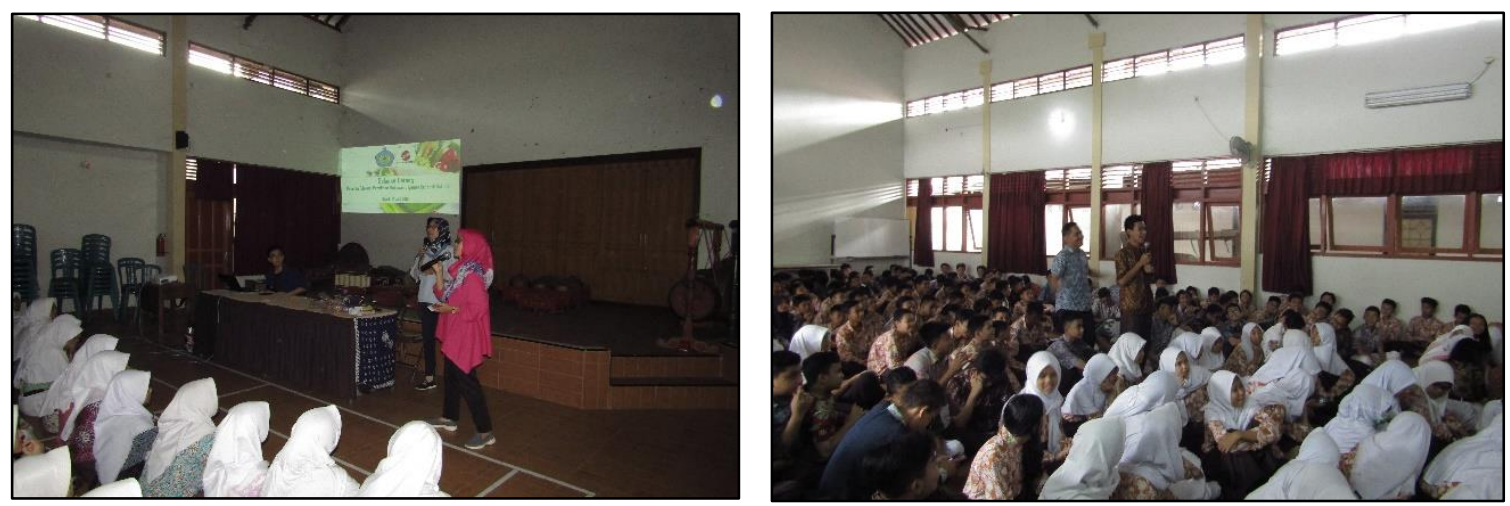

Gambar 1. Penyampaian Materi dan Diskusi
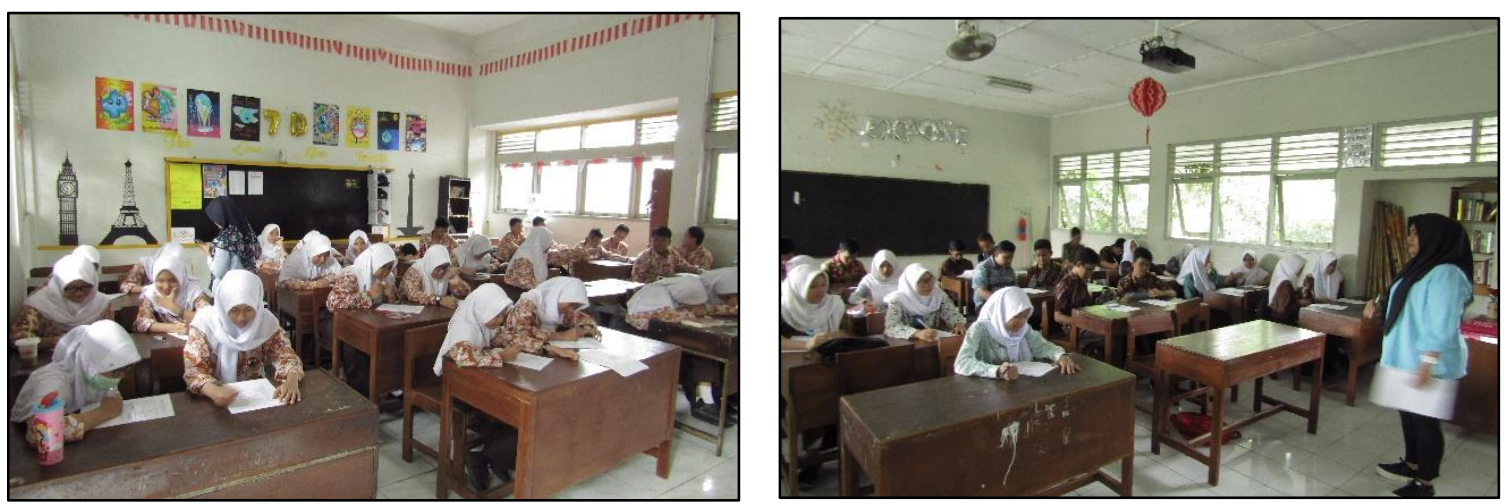

Gambar 2. Pre-test dan Post-test

Hasil pengamatan di kantin menunjukkan belum adanya peningkatan penyediaan fasilitas untuk penyelenggaraan kantin sehat. Alat masak dan alat makan belum tersimpan pada tempat tertutup; fasilitas mencuci tangan bagi konsumen kantin belum tersedia; tempat sampah tertutup belum tersedia dalam jumlah yang memadai; serta belum adanya media edukasi kesehatan di kantin seperti poster kebersihan dan gizi.

Pemilihan mitra pada kegiatan pengabdian kepada masyarakat dilakukan dengan mempertimbangkan ketersedian bangunan kantin sekolah yang permanen. Manajemen sekolah juga telah menunjuk beberapa guru untuk menjadi pengelola kantin sekolah. Pengelola kantin SMP Negeri 1 Depok, Sleman, Yogyakarta, merupakan salah satu peserta pada kegiatan edukasi mengenai pengelolaan kantin sehat di sekolah, yang telah dilaksanakan pada tahapan sebelumnya. Kegiatan ini direspon dengan baik pada saat pelaksanaan edukasi, hasilnya menunjukkan adanya perbedaan pengetahuan antara sebelum dan setelah pemberian materi edukasi (Prasetyaningrum \& Kadaryati, 2021). Peningkatan pengetahuan para kepala sekolah dan pengelola kantin sekolah diharapkan dapat menjadi awal pemikiran untuk menyelenggarakan kantin sehat di sekolah masing-masing.

Kegiatan edukasi penyelenggaraan kegiatan kantin sehat yang dilakukan oleh tim pengabdi sejak tahun 2018 , telah menyasar pada tiga kelompok sasaran yaitu pengelola kantin 
sebagai pihak yang berkontribusi dalam manajemen kantin di sekolah, petugas kantin, dan siswa sebagai konsumen di kantin sekolah. Ketiga kegiatan ini belum menghasilkan perwujudan kantin sehat di sekolah, tidak seperti teori yang disebutkan sebelumnya bahwa bahwa edukasi kesehatan mampu mengubah perilaku melalui proses peningkatan pengetahuan (Notoadmojo, 2014). Tim pengabdi telah melakukan wawancara kepada guru yang bertugas sebagai penanggung jawab pengelolaan kantin di SMP N 1 Depok. Berdasarkan hasil wawancara tersebut, pengelola sekolah belum menetapkan peraturan khusus mengenai pengadaan makanan di kantin sekolah. Peraturan yang ditetapkan sekolah mengenai pengadaan makanan di kantin masih terbatas, antara lain: adanya pelarangan penjamah makanan untuk menyediakan mie instan; belum ada aturan mengenai jajanan yang berlabel merah menurut standar traffic light labe/ seperti minuman instan atau softdrink. Selain itu, pihak sekolah juga tidak pernah memberikan edukasi kesehatan maupun peraturan mengenai higiene sanitasi yang harus diterapkan oleh penjamah makanan. Hal ini berkontribusi terhadap penyediaan jajanan di kantin sekolah. Petugas kantin menyediakan pilihan jajanan dengan mempertimbangkan aspek ekonomi, yaitu pangan jajanan yang banyak diminati oleh siswa, meskipun jajanan tersebut tergolong dalam makanan atau minuman dengan sebagai makanan yang tidak dianjurkan untuk tersedia di kantin.

Ada empat pilar dalam penyelenggaraan kantin sehat di sekolah, yaitu komitmen dan manajemen sekolah, sumber daya manusia, sarana dan prasarana, dan mutu pangan. Keempat pilar ini tidak dapat berjalan tanpa dukungan dari pilar lainnya (Februhartanty et al., 2018). Lebih lanjut dijelaskan bahwa selain warga sekolah, penyelenggaraan kantin sehat di sekolah juga membutuhkan dukungan dari orang tua/wali siswa (Rahayu et al., 2015).

Hasil pengabdian ini menyiratkan perlunya advokasi kepada manajemen sekolah selaku pihak yang berwenang dalam pengelolaan kantin sehat. Sekolah perlu menunjukkan komitmen dalam menyediakan makanan sehat dan aman untuk semua warga sekolah. Komitmen ini diwujudkan dalam pembangunan kantin sehat dan pengadaan fasilitas pendukung di kantin sehat sekolah, pengelolaan kantin sehat secara konsisten, pembentukan tim pengawas pangan jajanan, dan pembuatan kebijakan tertulis bagi para penjual di kantin dan nota kesepakatan antara pihak sekolah dan penjual (Februhartanty et al., 2018; Rahayu et al., 2015).

\section{Kesimpulan}

Edukasi mengenai gizi mampu meningkatkan pengetahuan siswa dan penjamah makanan tentang pemilihan makanan jajanan aman dan sehat. Namun, peningkatan pengetahuan ini belum cukup untuk mewujudkan penyelenggaraan kantin sehat di sekolah. Kantin SMP Negeri 1 Depok memiliki potensi untuk dikembangkan menjadi kantin sehat di sekolah mengingat adanya bangunan fisik yang permanen, serta penjamah makanan dan siswa yang telah mendapatkan edukasi. Untuk merealisasikan adanya kantin sehat di sekolah diperlukan dukungan pengelola sekolah berupa peningkatan fasilitas penunjang, seperti tempat penyimpanan peralatan, fasilitas cuci tangan, tempat sampah tertutup, serta poster gizi dan 
kesehatan sebagai media edukasi gizi. Di samping itu, diperlukan adanya kebijakan mengenai penyelenggaraan kantin sehat di sekolah.

\section{Ucapan Terima Kasih}

Tim pengabdi menyampaikan terima kasih kepada PPPM Universitas Respati Yogyakarta atas dukungan pendanaan dan koordinasi kegiatan pengabdian kepada masyarakat tahun 2019, serta segenap warga sekolah di SMP Negeri 1 Depok, Sleman, Yogyakarta atas kerja sama pelaksanaan kegiatan pengabdian kepada masyarakat.

\section{Referensi}

Anderson, P., Butcher, K., \& Levine, P. (2003). Economic Perspectives on Childhood Obesity. Economic Perspectives-Federal Reserve Bank of Chicago, 27(3), 30-48.

Anggraini, R. A., \& Djatmiko, A. A. (2019). Pemanfaatan Media Sosial (Group Whatsapp) dalam Menunjang Aktifitas Belajar Siswa di Luar Jam Sekolah di SMK Negeri 2 Tulungagung. Media Penelitian Pendidikan: Jurnal Penelitian Dalam Bidang Pendidikan Dan Pengajaran, 13(1), 1. https://doi.org/10.26877/mpp.v13i1.5082

Azwar, S. (2016). Sikap manusia teori dan aplikasinya. Pustaka Pelajar, Yogyakarta

Badan Penelitian dan Pengembangan Kesehatan Kementerian Kesehatan RI. (2010). Riset Kesehatan Dasar; Badan Penelitian dan Pengembangan Kesehatan Kementerian Kesehatan RI Tahun2010. Laporan Nasional 2010, 1-446.

BPOM. (2013). Pedoman Pangan Jajanan Anak Sekolah untuk Pencapaian Gizi Seimbang Bagi Orang Tua, Guru dan Pengelola Kantin. Direktorat Standardisasi Produk Pangan Deputi Bidang Pengawasan Keamanan Pangan Dan Bahan Berbahaya Badan Pengawas Obat Dan Makanan Republik Indonesia, 37. Diakses di: http://standarpangan.pom.go.id/dokumen/pedoman/Buku_Pedoman_PJAS_untuk_Pencapaian _Gizi_Seimbang_Orang_Tua_Guru_Pengelola_Kantin_.pdf

Cartagena, R. S. (2014). Are the foods and drinks in your school canteen healthy? An Assessment of the nutritional value of the foods and drinks sold at the School Canteens of De La Salle, Araneta University. Towards Rigorous, Relevant, and Socially Responsive Lasallian Research, 1-7.

Februhartanty, J., Iswarawanti, D. N., Ermayani, E., Meiyetriani, E., P., I. L., \& Astuti, R. D. (2018). Petunjuk Praktis Pengembangan Kantin Sehat Sekolah. SEAMEO RECFON, Jakarta

Hamida, K., Zulaekah, S. M. (2012). Jurnal Kesehatan Masyarakat Comics For Nutrition Counseling To Improve Snack Safety. Jurnal Kesehatan Masyarakat, 8(1), 67-73.

Kementerian Kesehatan Badan Penelitian dan Pengembangan Kesehatan 1. (2018). Hasil Utama Riskesdas 2018 Kementerian. Kementrian Kesehatan Republik Indonesia, 1-100. http://www.depkes.go.id/resources/download/info-terkini/hasil-riskesdas-2018.pdf

Lake, A. A. (2018). Neighbourhood food environments: Food choice, foodscapes and planning for health. Proceedings of the Nutrition Society, 77(3), 239-246. https://doi.org/10.1017/S0029665118000022

Mâsse, L. C., \& de Niet, J. E. (2013). School nutritional capacity, resources and practices are associated with availability of food/beverage items in schools. International Journal of Behavioral Nutrition and Physical Activity, 10, 1-12. https://doi.org/10.1186/1479-5868-10-26

Mensink, F., Schwinghammer, S. A., \& Smeets, A. (2012). The Healthy School Canteen programme: A promising intervention to make the school food environment healthier. Journal of Environmental and Public Health, 2012. https://doi.org/10.1155/2012/415746

Notoatmodjo, S. (2014). Promosi Kesehatan dan Perilaku Kesehatan. Rineka Cipta, Jakarta

Nurayu, A. W. (2013). Hubungan Tingkat Pengetahuan, Pendidikan, Usia Dan Lama Menjadi Kader Posyandu Dengan Kualitas Laporan Bulanan Data Kegiatan Posyandu. Jurnal Universitas Muhammadiyah Surakarta, 1-17.

Powell, P., \& Educator, U. E. (2016). Fact Sheet-10-11 What is Obesogenic Environment? September. Prasetyaningrum, Y. I., \& Kadaryati, S. (2021). Edukasi Penyelenggaraan Kantin Sehat pada 
Pengelola Sekolah di Wilayah Kecamatan Depok, Kabupaten Sleman, Yogyakarta. E-Dimas: Jurnal Pengabdian kepada Masyarakat, 12(1), 118-124. https://doi.org/10.26877/edimas.v12i1.5627

Rachmi, C. N., Li, M., \& Alison Baur, L. (2017). Overweight and obesity in Indonesia: prevalence and risk factors-a literature review. Public Health, 147, 20-29. https://doi.org/10.1016/j.puhe.2017.02.002

Rahayu, W. P., Nurulfalah, S., Pertanian, F. T., East, S., Food, A., \& Science, A. (2015). Perubahan Sikap Keamanan Pangan Siswa Berdasarkan Persepsi Orang Tua dan Anak. 2(2), 112-118.

Rohmah, M. H., Rohmawati, N., \& Sulistiyani, S. (2020). Hubungan kebiasaan sarapan dan jajan dengan status gizi remaja di Sekolah Menengah Pertama Negeri 14 Jember. I/mu Gizi Indonesia, 4(1), 39. https://doi.org/10.35842/ilgi.v4i1.155

Sari, M. P., Palupi, I. R., \& Jamil, M. D. (2016). Persepsi Dan Sikap Konsumen Terhadap Penerapan Traffic Light Card Pada Produk Pangan Kemasan (Consumer's Perception and Attitude Towards Implementation of Traffic Light Card for Packaged Food Products). Nutrition and Food Research, 39(1), 27-36. Sumarni, N., Rosidin, U., \& Sumarna, U. (2020). Penyuluhan Kesehatan Tentang Jajanan Sehat Di Sekolah Dasar Negeri Jati III Tarogong Kaler Garut. Kumawula: Jurnal Pengabdian Kepada Masyarakat, 3(2), 289-297.

Suryani, R. (2017). Fungsi Whatsapp Grup Shalihah Cabang Bandar Lampung Sebagai Pengembangan Media Dakwah Dalam Membentuk Akhlakul Karimah. 23-24. http://repository.radenintan.ac.id/779/

Syafirah, S., \& Andrias, D. R. (2012). Higiene Penjamah Makanan dan Sanitasi Kantin Sekolah Dasar Negeri di Kecamatan Mulyorejo, Surabaya. Media Gizi Indonesia, 10(2), 111-116. https://ejournal.unair.ac.id/MGI/article/viewFile/3314/2358

Templeton, S. B., Marlette, M. A., \& Panemangalore, M. (2005). Competitive foods increase the intake of energy and decrease the intake of certain nutrients by adolescents consuming school lunch. Journal of the American Dietetic Association, 105(2), 215-220. https://doi.org/10.1016/j.jada.2004.11.027

Timmermans, J., Dijkstra, C., Kamphuis, C., Huitink, M., van der Zee, E., \& Poelman, M. (2018). 'Obesogenic' School Food Environments? An Urban Case Study in the Netherlands. International Journal of Environmental Research and Public Health, 15(4). https://doi.org/10.3390/ijerph15040619 